dokładnie prześledzić zasadność tego przekonania, wertując niezwykłą książkę Isreala: „The French Revolution was qualitatively different from all known previous revolutions and also remains more fundamental for us than subsequent revolutions thus far, more fundamental, for example, than the Russian Revolution. The reason consists in the Revolution's special relationship to the Enlightenment, and especially to the Enlightenment's republican, democratic, and secularizing radical wing. It was especially foundational in that it fed into all later revolutions in Europe, Latin America, and Asia, fixing both the contours and dilemmas of modern republicanism, constitutional monarchy, and democracy, and introducing the social and constitutional principles that defined the modern political world. The only democratic revolution thus far that conceived democracy as the pursuit of the majority's welfare, assigning government the duty to promote the welfare of all as a society and combat economic inequality rather than just maintain order and defend property, it was the first sustained attempt to establish a secular, educated, welfare-oriented, human roghts-based modernity. It sought maximization of »social freedom« combined with equal opportunities for all. All this affords the French Revolution a unique centrality in modern history and relevance to the challenges of our own time" [696].

DOI 10.14746/SO.2014.71.23

WIESŁAW RATAJCZAK

Poznań

\title{
Skromny gest pożegnania
}

\author{
Edward P i e ś c i k o w s ki, Bolestaw Prus - „humorysta w wielkim stylu”. Studia i szkice, Wy- \\ dawnictwo Poznańskie, Poznań 2012, ss. 249.
}

Bolesław Prus - „humorysta w wielkim stylu” Edwarda Pieścikowskiego to książka skromna. Niezbyt obszerna, złożona z krótkich szkiców, opatrzona tytułem, w którym nazwisko pozytywisty uzupełnione zostało autorską formułą, a niżej dodano szablonowy dopisek: Studia i szkice. Można by w pierwszym odruchu uznać tę publikację za efekt przeglądu dorobku historyka literatury, dla wygody czytelników sporządzony zbiór dotąd rozproszonych studiów o ulubionym pisarzu. To jednak coś znacznie ważniejszego.

Książkę rozpoczyna szkic Prus i pieniądze. Składa się nań ledwie kilka stron okraszonych anegdotami, lecz jednocześnie taktownie nakreślony został tu portret autora Lalki jako jednego z pierwszych polskich zawodowych pisarzy, odmierzającego życie skromnie opłacaną wierszówką, z trudem układającego sobie relacje z wydawcami i osiągającego nieszczególnie wygórowane dochody. W finale szkicu pada informacja, że Prus dorobił się „welocypedu (kupionego na raty), maszyny do pisania i aparatu fotograficznego marki „Kodak”” (17). Humorystycznie i gorzko obrazując ascetyczną egzystencję pisarza, Pieścikowski wprowadził przy okazji kilka kwestii o kapitalnym znaczeniu dla interpretacji literatury. Zapytał: Jaka jest rola wątków ekonomicznych w powieści? Jak w nowoczesnym świecie praktykować miłosierdzie? Czy bogactwo musi demoralizować? Jak drobne a rozumne wsparcie może dosłownie uratować czyjejś życie? Gdy te pytania postawić, Lalka wydaje się traktować bardziej o splocie interesów materialnych i moralności niż o afekcie kupca do arystokratki. Pieścikowski zauważył żartobliwie (choć nie bez nakładu pracy, bo to szkic sprzed doby komputerowych programów, w kilka sekund wykonujących podobne zadania), że słowo „miłość” występuje w Lalce 104 razy, zaś „pieniądz” 229, a „rubel” dodatkowo 407. Ciekawostka? Nie, raczej ważna sugestia interpretacyjna, w której rozwinięciu autor czytelnika już nie wyręczył.

Pieścikowski często fundamentem interpretacji czynił proste zadanie filologiczne. Studium Od „Chybionej powieści” do „Anielki” oparł na procedurze, której pomysłodawcą i wykonawcą mógłby być początkujący adept historii literatury, mianowicie na porównaniu wersji czasopiśmienniczej i wydania książkowego. Efekt tej prostej 
czynności okazał się niezwykle ważny. Odkryły się bowiem warstwy literackiej świadomości pisarza, jego polemika z gustami epoki, z obowiązującymi konwencjami gatunkowymi, a także wyczulenie na specyfikę odbioru dzieła literackiego. Do takich poznawczych efektów doprowadziła m.in. analiza zmian, jakie zaszły między edycją gazetową a książkową w tytulaturze rozdziałów. Autora studium interesowało Prusowe przemieszanie konwencji tytułów, wypróbowywanie różnorodnych perspektyw narracyjnych (od wszechwiedzy do elementów narracji personalnej). Analiza dwóch wersji zakończenia doprowadziła do refleksji nad pesymistyczną wymową ideową dzieła. Tak wielostronnie odczytana Anielka okazała się ważnym ogniwem ewolucji sztuki Prusa, autora w poszukiwaniu własnej formuły powieściowej.

Nie lekceważmy drobiazgów, zdaje się powtarzać Pieścikowski w tym i pozostałych szkicach. I zaraz dodaje - wiążmy nici przeszłości, odkrywajmy, jak łączą się sprawy publiczne z prywatnymi, głośne fakty z wydarzenia, o których nie pamiętają historycy. Wzorcowym przykładem zastosowania tej metody jest szkic Geneza „Omytki”. Pod tym skromnym tytułem kryje się nie tylko wyjaśnienie okoliczności powstania jednego z ważniejszych opowiadań pozytywistycznych, ale także refleksja o relacjach między pisarzem a opinią publiczną w realiach drugiej połowy XIX wieku. W Omyłce usłyszał historyk literatury echa osobistych doświadczeń Prusa z marca 1878 roku, kiedy jego bezkompromisowe wypowiedzi publicystyczne stały się przyczyną fizycznej napaści na warszawskiej ulicy. Wymieniając zdarzenia, które mogły zainspirować autora Omyłki, Pieścikowski wskazał także sprawę Józefa Ignacego Kraszewskiego. Właśnie w roku 1884 (więc wtedy, gdy Prus pisał opowiadanie) sędziwy autor Starej baśni został przez władze pruskie aresztowany i osądzony pod zarzutem szpiegostwa na rzecz Francji. Prus nie zajmował się kwestią wiarygodności aktu oskarżenia, oburzało go natomiast odcięcie się polskiej prasy od twórcy, jeszcze tak niedawno powszechnie uwielbianego. Dzięki temu studium opowiadanie, dotąd odczytywane przede wszystkim w kontekście literackiej antylegendy Powstania Styczniowego, okazało się głosem w sprawie wolności pisarza wobec dyktatu ogółu.

Po tej rekonstrukcji okoliczności powstania jednego utworu Pieścikowski proponuje w swej książce kolejne filologiczne zadanie. Zachęca do tego, by największą powieść Prusa przeczytać tak, jak czytali ją pierwsi odbiorcy, czyli w gazetowych odcinkach. Warto dodać, że zainspirował do tego ćwiczenia także Józefa Bachórza, edytora Lalki. W recenzji pierwszego wydania powieści w serii Biblioteka Narodowa postulował Pieścikowski wprowadzanie znaków podziału między odcinkami oraz dat ich publikacji, w drugim wydaniu te elementy już się znalazły. Studiując Lalke jako „,serial” (,emitowany” od 29 IX 1887 do 24 V 1889 w „Kurierze Codziennym"), zobaczyć można, że Prus - być może, jako jedyny polski powieściopisarz - w pełni zrozumiał zasady poetyki odcinkowej i specyfikę odbioru tej formy. Z pozoru banalne i uciążliwe ćwiczenie, jakim jest porównanie pierwodruku prasowego z edycją książkową, pozwoliło odkryć wewnętrzną dynamikę dzieła, rozmaite sposoby rekapitulowania wydarzeń na użytek roztargnionych czytelników, różnorodność form wprowadzania nowych postaci etc. Dzięki Pieścikowskiemu współczesny czytelnik może w pełni docenić to, że Prus świadomie korzystał z dwóch mediów: gazety i książki.

Następne w zbiorze studium o Emancypantkach zaczyna się od standardowych dla historyka literatury pytań: o kompozycję, otwarty charakter zakończenie, sposób kreowania postaci literackich. I gdy czytelnikowi może się wydawać, iż nie otrzyma nic poza standardowymi spostrzeżeniami z zakresu poetyki historycznej, niepostrzeżenie zostaje wciągnięty w rozmowę o sprawach najważniejszych. Emancypantki okazują się powieścią nie tylko o skomplikowanych okolicznościach dziewiętnastowiecznego usamodzielniania się kobiet i o niepokojach duszy wchodzącej w dorosłość nastolatki. W powieści z 1894 roku najaktualniejsze okazują się argumenty przeciw pesymizmowi i samobójczej rozpaczy.

Podobny naddatek oczekuje na czytelnika szkicu Mickiewicz - ,wychowawca narodu’. Na pierwszy rzut oka jest to okolicznościowy artykuł o stosunku Prusa do wieszcza. Oczywiście, warto było przypomnieć, jak autor Lalki odnosił się do kultu romantycznego poety, jak czytał jego utwory, jak traktował pomysł wzniesienia pomnika w Warszawie. Pieścikowski rzetelnie te kwestie zrelacjonował, dyskretnie dodając opowieść o swoistym porozumieniu zawiązanym przez pozytywistę z romantykiem. W Mickiewiczu filomacie rozpoznał bowiem Prus twórcę programu organicznego. Pieścikowski skonstatował to z pewnym rozbawieniem, jednocześnie jednak pokazał nici zszywające epokę, którą z perspektywy współczesnej skłonni jesteśmy dzielić na nieprzystające do siebie, kontrastowo różne fragmenty.

Temat szkicu Niezrealizowane pomysty literackie również początkowo nie sprawia wrażenia atrakcyjnego. W przypadku wybitnych pisarzy niewątpliwie warto skatalogować te zamierzenia, które pozostały w sferze planów, fragmentów, notatek. Znając biogram Prusa, łatwo się domyślić, że jedną z przyczyn porzucania przedsięwzięć był po prostu brak czasu lub fizyczne wyczerpanie (warto przy tym dostrzec ten dramatyczny wybór pisarza, angażującego się w działania publiczne kosztem własnej twórczości). Pieścikowski ukazał jednak także inne powody. Niektóre fantastyczne pomysły przychodziło zostawić, gdyż pisarz zdawał sobie sprawę z własnych 
ograniczeń warsztatowych. Wiele spośród projektów zanotowanych przez Prusa świadczy o tym, że próbował zająć stanowisko wobec nowej, młodopolskiej estetyki. Jak ostrożnie zauważył Pieścikowski, Prus „,zapisywał wciąż nowe pomysły fabularne, snuł śmiałe projekty literackie, a równocześnie - jakby stracił wiarę w wystarczalność realistycznych środków wyrazu" (134). Artykuł zaczynający się jak niepozorny przyczynek zamienia się w studium o skomplikowanych relacjach pozytywistycznego pisarza z literackim modernizmem. Prus na nowe propozycje wcale nie był zamknięty, jak mogłoby się wydawać, gdyby nie zaglądać do jego osobistych notatek.

Kwestię zrealizowanych i zarzuconych planów podjął Pieścikowski także w studium Od aforyzmu do tematu. Punktem wyjścia jest w tym przypadku fakt także, wydawałoby się, małej rangi, mianowicie ówczesna moda na złote myśli. Trendowi temu nie oparł się i Prus, skoro wyraził zgodę się publikację wyboru swoich sentencji, a w księgozbiorze posiadał sporo wydawnictw o takim charakterze. Okazuje się, że w notatnikach utożsamił aforyzm z tematem, Pieścikowski zasugerował więc, by podjąć studia o związkach między zapisanymi przez pisarza maksymami a jego opowiadaniami i powieściami. Być może dzieła literackie były swoistym polem weryfikacji sądów o charakterze uogólniającym.

Pierwszą część książki wypełniają więc studia o dziełach pozytywisty, w drugiej zebrane zostały artykuły na temat ich recepcji. Pieścikowski, autor prekursorskich opracowań dotyczących krytycznego i naukowego odbioru dzieł autora Lalki, rozpoczął od stwierdzenia, że nie było legendy Bolesława Prusa, co odróżnia go zwłaszcza od romantyków. Czytelnik szkicu - pierwotnie opublikowanego jako wstęp do antologii - otrzymuje nie tylko miarodajny przegląd stanowisk wobec spuścizny wielkiego pisarza, przy okazji dyskretnie wprowadzona została także refleksja o zmiennym stosunku do przeszłości i tradycji, analiza zachodzących w czasie zmian w sytuacji literatury, w sposobie rozumienia zadań i metod krytyki.

Jeden z aspektów recepcji obszerniej pisał Pieścikowski w artykule Bolesław Prus - pisarz niepopularny. Tym zaskakującym tytułem opatrzył rozważania o tym, jak krytycznie oceniał Prus Wielkopolan i jak był przez nich samych odbierany. Uwagi o, eufemistycznie rzecz ujmując, niezbyt entuzjastycznym odbiorze twórczości autora Lalki w zaborze pruskim prowadzą do wniosków o ograniczeniach narzucanych przez wpływowe kręgi ziemiańskie i o użytkowym charakterze publikowanej tu literatury. Przykładem utylitarnego podejścia jest popularna w Poznańskiem „Placówka dla ludu”, jak Pieścikowski nazywa przeróbkę sporządzoną przez Faustynę Morzycką, a opublikowaną pod tytułem O ojcowiznę, czyli jak sobie jeden chłop z Niemcami poradził. Autor studium świetnie ukazał na tym przykładzie relacje między obiegami literackimi - wysokoartystycznym i popularnym.

Dopełnieniem szkiców o recepcji Prusa są artykuły o adaptacjach teatralnych i filmowych. Przypominając aż trzy sceniczne przeróbki Powracajacej fali, jakich dokonano w pierwszym dziesięcioleciu PRL, Pieścikowski nie tylko zwrócił uwagę na dramatyczny potencjał prozy Prusa, ale przy okazji zaprezentował także próby przykrojenia pozytywistycznego opowiadania do wymagań poetyki realizmu socjalistycznego. Krytyczna ocena filmowych wersji Emancypantek (Pensja Pani Latter w reżyserii Stanisława Różewicza) i Lalki (Wojciecha J. Hasa) doprowadziła autora szkicu do wniosku, że najważniejszą cechą prozy Prusa jest uwewnętrznienie narracji: „Proza to w swej warstwie introspekcyjnej trudno przekładalna na język filmowy. A przecie bez tych wszystkich „myśli”, „medytacji”, „marzeń,, „widzeń” i „widziadeł” (określenia wzięte z tytułów rozdziałów Lalki i Emancypantek) bohaterowie tracą - jakże charakterystyczną - wieloznaczność, stają się jednowymiarowi, jakby spłaszczeni. W następstwie prozę Prusa odziera się z relatywizmu psychologicznego, szerzej - z relatywizmu poznawczego" (237). Znów więc podjęcie z pozoru błahego zadania, jakim jest sporządzenie komentarza do ekranizacji dzieł ulubionego pisarza, doprowadziło autora do kapitalnych wniosków.

Jak dziś pisać o literaturze sprzed wielu dziesięcioleci? Nie sposób na to pytanie udzielić odpowiedzi kompletnej i ostatecznej. Jednak poszukując własnego rozwiązania, warto sięgać po dobre, sprawdzone wzory. Autor książki o Prusie nie korzystał gorliwie z dobrodziejstw współczesnych metodologii, a tym bardziej - nie usiłował nadążyć za intelektualnymi modami. Rozpoczynał od zrekonstruowania genezy dzieła, ukazania go w naturalnym, współczesnym środowisku, często w związkach z biografią pisarza i jego osobistymi wyborami ideowymi. Bez skrępowania sięgał po podstawowe pojęcia z zakresu poetyki historycznej, przyglądając się kompozycji, kreacji postaci, genologii. A wielka literatura tę powściągliwą postawę naukowca nagradzała, odsłaniając przed nim najistotniejsze swe cechy.

Nie można nie wspomnieć o szacunku dla czytelnika jako cesze wyróżniającej autora. Pieścikowski nigdy nie wprowadzał odbiorcy w zakłopotanie, nie epatował terminologią, nie obezwładniał erudycyjnymi popisami. Nie adresował przecież swych studiów tylko do wąskiego kręgu historyków literatury, lecz pisał z myślą o szerokim gronie miłośników twórczości Prusa, których znaleźć można w różnych środowiskach. Profesor Pieścikowski 
łączył w swoim pisarstwie (i sztuce wykładania literatury) dwie postawy: był precyzyjnym profesjonalistą, a jednocześnie pozostawał amatorem, we właściwym, etymologicznym znaczeniu tego słowa.

Artykuły zebrane w tej książce są błyskotliwymi zarysami i zapowiedziami obszernych studiów. Niestety nie napisze ich Edward Pieścikowski. Profesor zmarł 17 maja 2014 roku. Książka, z pietyzmem ułożona przez Tomasza Sobieraja i przejrzana przez Autora, stała się formą pożegnania. Biorąc ją do rąk, trudno nie pomyśleć o dotkliwej stracie, jednocześnie jednak przypominają się słowa z finału Kamizelki: „Któż jednak powie, że za tymi chmurami nie ma słońca?..."

DOI 10.14746/SO.2014.71.24

ANNA GAWARECKA

Poznań

\section{Nie tylko Szwejk. Czeska literatura w perspektywie genderowej}

Marcin F i l i p ow i c z, Panowie, bądźmy Czechami, ale nikt nie musi o tym wiedzieć... Wzorce męskości w kulturze czeskiej XIX wieku, Wydawnictwo Uniwersytetu Jagiellońskiego, Kraków 2013, ss. 298

Monografia „Panowie, bądźmy Czechami, ale nikt nie musi o tym wiedzieć...” Wzorce męskości w kulturze czeskiej XIX wieku jawi się jako ukoronowanie genderowych eksploracji, definiujących zainteresowania naukowe Marcina Filipowicza, zarysowane przede wszystkim we wcześniejszej jego książce Urodzić naród. Z problematyki czeskiej i stowackiej prozy kobiecej II połowy XIX wieku (Warszawa 2008). Stanowi jednocześnie interesujący przyczynek do przeorientowania utrwalonego w badaniach obrazu podstawowych wyznaczników czeskiej literatury dziewiętnatowiecznej. Już we wstępie Autor informuje, że u podstaw jego rozważań leży potrzeba krytycznego spojrzenia na utrwalone truizmy bohemistyczne, konkretnie zaś - na zakorzenione w myśli kulturo- i literaturoznawczej przeświadczenia dotyczące rudymentarnych aksjomatów ideologii czeskiego odrodzenia narodowego. Tekst książki podzielony został na cztery części, podporządkowane pod względem tematycznym podstawowym zjawiskom, hasłom i kategoriom refleksji budzicielskiej. Filipowicz przygląda się w nich zatem kolejno: lingwistycznym aspektom postrzegania męskości (Męskość w języku s. 27-64); modelowaniu wzorców męskości w czeskiej literaturze lat 30. - 70. XIX wieku (Literacka wizja narodowej męskości, s. 65-136); roli kultury popularnej w kształtowaniu, propagowaniu i umacnianiu tychże wzorców (Męskości umasowione, s. 137-198) oraz ich ujęciom pamiętnikarskim (Pamięć męskości, s. 199-267). Punktem wyjścia wszystkich rozważań pozostaje tu jednak prześledzenie poglądów badaczy zachodnich zajmujących się przemianami postrzegania roli, pozycji czy preferowanych stylów zachowań mężczyzny w dziewiętnastowiecznym europejskim społeczeństwie. Zastanawia natomiast w tej sytuacji nikła obecność kontekstu polskiego, bliższego wszakże (ze względu na polityczne i ideologiczne uwarunkowania, niezależnie nawet od realnych, bezpośrednich związków i kontaktów) sytuacji czeskiej niż pozbawiony potrzeby obrony bytu narodowego kontekst zachodnioeuropejski.

Autor powołuje się zatem na wnioski opisujące doświadczenia odległe od doświadczeń czeskich i koncentrujące uwagę przede wszystkim wokół ukształtowanej wewnątrz oświeceniowego projektu antropologicznego kategorii tzw. męskości hegemonicznej, na dalszy plan spychającej i dezawuującej inne - konkurencyjne czy alternatywne - warianty męskiej tożsamości. Ta rekonstrukcja refleksji dotyczącej wzorców męskości służy Filipowiczowi z jednej strony jako teoretyczne podglebie dla własnych naukowych eksploracji, z drugiej strony zaś zmusza go do wszczęcia polemiki z opiniami dążącymi do uniwersalizacji jednego absolutyzowanego modelu. Refleksje te poddane zostają w monografii daleko idącej rewizji, dowodzącej ich nieprzystawalności do sytuacji czeskiej, w której konieczność wytworzenia własnych konceptów tożsamościowych obligowała niejako 